\title{
O WPLYWIE NIEMETALICZNEGO ZBROJENIA GŁÓWNEGO NA MECHANIZM NISZCZENIA I NOŚNOŚĆ ŚCINANIA BETONOWYCH BELEK BEZ ZBROJENIA POPRZECZNEGO
}

\begin{abstract}
W pracy przedstawiono wyniki doświadczalnych badań belek bez zbrojenia poprzecznego zbrojonych na zginanie prętami wykonanymi z włókien szklanych. Celem badań była analiza zachowania się belek pod obciążeniem wraz z określeniem wpływu intensywności tego zbrojenia na sposób niszczenia i nośność ścinania. Do analizy odkształcalności i rozwoju zarysowania elementów badawczych użyto systemu cyfrowej korelacji obrazu ARAMIS. Korzystając z kinetycznego modelu ścinania opisano proces niszczenia belek oraz określono położenie i nachylenie ukośnych rys niszczących. Badania wykazały, że niszczące naprężenia ścinające rosną wraz ze wzrostem stopnia zbrojenia głównego, przy czym wpływ liczby prętów i ich średnicy - w ramach grupy belek o jednakowym stopniu zbrojenia - na ogół nie był istotny, większe znacznie miała liczba warstw prętów, zwłaszcza przy najwyższym stopniu zbrojenia.
\end{abstract}

Słowa kluczowe: belka betonowa, zbrojenie niemetaliczne, pręt GFRP, nośność na ścinanie, mechanizm zniszczenia, zarysowanie, naprężenie ścinające, stopień zbrojenia

\section{Wprowadzenie}

Jednoczesne występowanie siły tnącej i momentu zginającego w przypodporowych obszarach żelbetowych ustrojów prętowych jest przyczyną złożonego stanu naprężenia. Przy założeniu płaskiego stanu naprężenia w tym obszarze, $\mathrm{w}$ ortogonalnym układzie współrzędnych $\mathrm{w}$ niezarysowanym betonie występują naprężenia styczne $\tau_{x y}=V S_{0} /(b I)$ oraz naprężenia normalne $\sigma_{x}=M z / I$, gdzie $V$ i $M$ oznaczają odpowiednio siłę poprzeczną i moment zginający w rozpatrywanym przekroju, $S_{0}$ - moment statyczny pola leżącego ponad rozpatrywanym pozio-

\footnotetext{
${ }^{1}$ Autor do korespondencji / corresponding author: Renata Kotynia, Politechnika Łódzka, renata.kotynia@p.lodz.pl

${ }^{2}$ Monika Kaszubska, Politechnika Łódzka, monika.dymecka@p.lodz.pl
} 
mem o współrzędnej $z$, względem środka ciężkości przekroju, $b$ i $I$ - odpowiednio szerokość i moment bezwładności przekroju.

Dotychczasowe normowe metody obliczeniowe dotyczące ścinania w elementach żelbetowych traktują rozłącznie wpływ siły poprzecznej i momentu zginającego w rozważanym przekroju, co prowadzi do odrębnego sprawdzania przekroju na zginanie (z uwzględnieniem występującego w przekroju momentu zginającego i odpowiadającego mu zbrojenia podłużnego) oraz na ścinanie (z uwzględnieniem siły poprzecznej i odpowiadającego zbrojenia poprzecznego) [3]. Największy jak dotąd przegląd badań żelbetowych belek bez zbrojenia poprzecznego opracował Reineck [7], uzasadniając w swoich pracach opinię o różnej nośności betonu na ścinanie w elementach bez zbrojenia poprzecznego i w elementach zbrojonych poprzecznie. W pracy [7] Reineck udowodnił, że efekt skali ma duży wpływ na nośność ścinania tylko w elementach bez zbrojenia na ścinanie, podczas gdy w elementach $\mathrm{z}$ takim zbrojeniem nie ma on istotnego znaczenia. Nośność betonu w elementach bez zbrojenia poprzecznego wyznacza się przy założeniu, że beton przenosi naprężenia rozciągające oraz jego nośność istotnie zależy od zbrojenia podłużnego pod warunkiem, że jest ono dobrze zakotwione na podporze [3].

To klasyczne podejście do zagadnienia ścinania, szeroko publikowane w literaturze, stało się podstawą wszystkich zaleceń normowych, dotyczących elementów żelbetowych bez zbrojenia poprzecznego. Te same zależności obliczeniowe stosowane są zarówno dla przekrojów położonych w obszarach skrajnych podpór belek swobodnie podpartych, jak i środkowych podpór belek wieloprzęsłowych. Podczas gdy w obu tych przekrojach udział momentu zginającego jest skrajnie różny, nieznaczny przy podporach skrajnych i dominujący w obszarach podpór środkowych.

Zastosowanie zbrojenia podłużnego wykonanego z prętów kompozytowych (fiber reinforced polymer-FRP) zwiększa stopień trudności zagadnienia ścinania z powodu silnie anizotropowej budowy kompozytów oraz wartości modułu sprężystości poprzecznej, który jest wielokrotnie niższy, niż moduł sprężystości stali, a dodatkowo zmienność tego modułu waha się w bardzo dużych granicach od $35 \mathrm{GPa}$ do $148 \mathrm{GPa}$ (w zależności od typu włókien).

Zdania na temat wpływu rodzaju zbrojenia na nośność ścinania są podzielone, a szczegółowa interpretacja wyników kłopotliwa z uwagi na ogromne zróżnicowanie parametrów zmiennych. Szczegółową analizę stanu wiedzy w tym temacie i wpływu parametrów zmiennych na nośność ścinania belek bez zbrojenia poprzecznego autorki przedstawiły [4]. Wynika z niej, że wyraźnie niższy moduł sprężystości zbrojenia kompozytowego, w porównaniu z tradycyjnym zbrojeniem stalowym, zmniejsza nośność na zginanie, powoduje silniejsze zarysowanie od zginania, a tym samym osłabia efekt siły klockującej zbrojenia podłużnego, co z kolei wpływa na niższą nośność ścinania. Na podstawie zebranej bazy wyników badań obcych autorki wykazały w [4], że smukłość ścinania a/d najbardziej wpływa na nośność strefy przypodporowej, co sprawia, że przy ald $\leq 3,0$ pozo- 
stałe parametry zmienne są zdominowane właśnie wpływem smukłości ścinania. Natomiast w belkach o smukłości ścinania ald > 3,0 wyraźnie widoczny jest wzrost nośności ścinania wraz ze wzrostem osiowej sztywności zbrojenia podłużnego $\rho E$, tym większy, im wyższy jest moduł sprężystości tego zbrojenia [4].

\section{Badania doświadczalne}

Motywacją do podjęcia badań belek na ścinanie była chęć autorek do własnych obserwacji niszczenia belek z głównym zbrojeniem wykonanym z włókien szklanych oraz szczegółowa analiza mechanizmu niszczenia w aspekcie rodzaju zbrojenia, jego stopnia i sposobu ułożenia (w jednej lub dwóch warstwach, różnej liczby i średnicy prętów). Na podstawie analizy badań obcych [4] założono w obecnym programie badawczym, że smukłość ścinania $a / d=2,9$ zapewnia brak wpływu efektu łukowo-ściągowego. Należy dodać, że opisane w pracy badania własne stanowią część szerszego programu badawczego, uwzględniającego ponadto wpływ rodzaju zbrojenia (GFRP/stalowe) oraz grubości betonowej otuliny na nośność i odkształcalność belek bez zbrojenia poprzecznego. Nadrzędnym celem badań była analiza procesu niszczenia na ścinanie takich elementów, szeroko publikowana jak dotąd tylko w odniesieniu do elementów żelbetowych.

Program badawczy obejmował siedem jednoprzęsłowych, swobodnie podpartych belek o przekroju teowym $\left(b_{\text {eff }}=400 \mathrm{~mm}, b_{w}=150 \mathrm{~mm}, h_{f}=60 \mathrm{~mm}\right.$, $h_{\text {tot }}=400 \mathrm{~mm}$ ) i rozpiętości w osiach podpór $1800 \mathrm{~mm}$. Jak dotąd żadne z publikowanych badań elementów ze zbrojeniem niemetalicznym nie miały przekroju teowego. Belki obciążano siłą skupioną położoną w odległości $1100 \mathrm{~mm}$ od osi podpory, przy której analizowano odcinek ścinania (rys. 1.). W celu analizy wpływu zbrojenia podłużnego założono trzy stopnie tego zbrojenia $\rho \approx 1,0 \%$, $1,4 \%$ i $1,8 \%$. W ramach każdego z trzech stopni zbrojenia poddano analizie liczbę i średnicę prętów oraz liczbę poziomów tego zbrojenia (np. dla $\rho \approx 1,0 \%$ belki zbrojone 5Ø12; $3 \varnothing 16 \mathrm{w}$ jednej warstwie i $3 \emptyset 12+2 \varnothing 12$ - w dwóch warstwach, rys. 1, Tab. 1). Główne zbrojenie wykonano z prostych odcinków prętów GFRP o średnicach $12 \mathrm{~mm}, 16 \mathrm{~mm}$ i $18 \mathrm{~mm}$. Wszystkie pręty zakotwiono w stalowych skrzynkach wypełnionych zaprawą klejową (rys. 1.). Zbrojenie górne stanowiły dwa pręty GFRP o średnicy $10 \mathrm{~mm}$ połączone krótkimi poprzecznymi prętami o średnicy $6 \mathrm{~mm}$, ułożonymi w półce przekroju teowego w rozstawie $210 \mathrm{~mm}$. Przeciwległą strefę przypodporową belki zabezpieczono przed zniszczeniem na ścinanie poprzez zastosowanie silnego zbrojenia poprzecznego, które stanowiły stalowe strzemiona z prętów o średnicy $8 \mathrm{~mm}$ w rozstawie $130 / 150 \mathrm{~mm}$ oraz stalowe pręty odgięte o średnicy $14 \mathrm{~mm}$ (rys. 1). Wszystkie belki opisanej serii miały betonową otulinę grubości $15 \mathrm{~mm}$. Dla łatwej identyfikacji elementów przyjęto jednolity sposób opisu belek: G- $\emptyset \emptyset / m \emptyset-30-15$, gdzie G oznacza zbrojenie GFRP, $n \emptyset$ - liczbę prętów o średnicy $\emptyset \mathrm{w}$ niższym lub $m \emptyset \mathrm{w}$ wyższym poziomie zbrojenia, jeżeli zbrojenie ułożono w dwóch warstwach. 


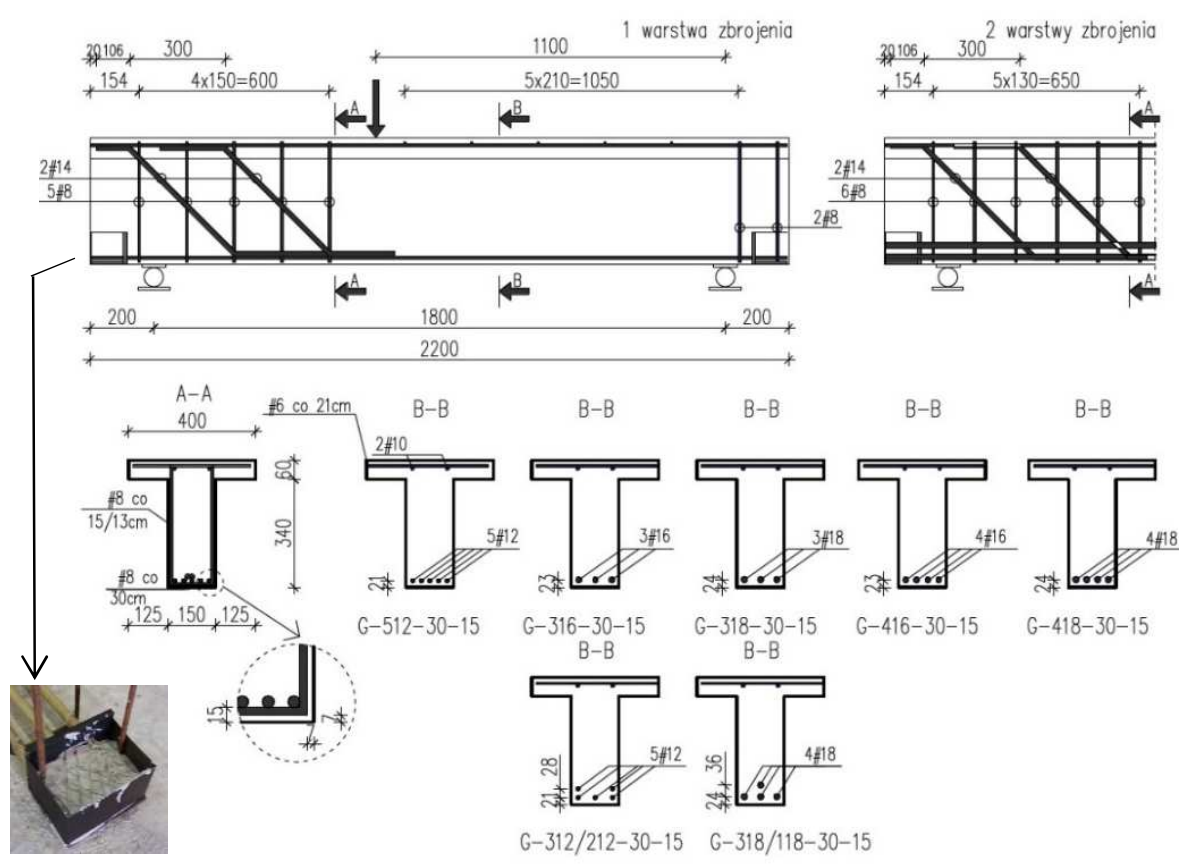

Rys. 1. Sposoby zbrojenia belek

Fig. 1. Configuration of reinforcement in the beams

Belki wykonano z gotowej mieszanki betonu towarowego klasy $\mathrm{C} 25 / 30$ o składzie: piasek $0 / 2\left(970 \mathrm{~kg} / \mathrm{m}^{3}, 42.33 \%\right)$, kruszywo łamane $2 / 8\left(860 \mathrm{~kg} / \mathrm{m}^{3}\right.$, $37.53 \%)$, woda $\left(205 \mathrm{~kg} / \mathrm{m}^{3}, 8.94 \%\right)$, CEM I 42,5 Rudniki $\left(255 \mathrm{~kg} / \mathrm{m}^{3}, 11.13 \%\right)$ oraz plastyfikator $\left(1.8 \mathrm{~kg} / \mathrm{m}^{3}, 0.07 \%\right)$. Podczas betonowania belek wykonano standardowe próbki walcowe $(150 \mathrm{~mm} \times 300 \mathrm{~mm})$ oraz sześcienne o boku $150 \mathrm{~mm}$ do określenia cech wytrzymałościowych betonu. Wytrzymałość na ściskanie i moduł sprężystości określono w dniu badania belek na próbkach walcowych, a wytrzymałość na rozciąganie metodą rozłupywania na próbkach kostkowych (tab. 1.). Charakterystykę zbrojenia GFRP określono w badaniach na rozciąganie sześciu próbek z każdej średnicy, dla których średni moduł sprężystości wynosił 50,5 GPa, a średnia wytrzymałość na rozciąganie $1091 \mathrm{MPa}$.

Belki oparto na przegubowych podporach, z których jedna, położona po stronie analizowanego odcinka ścinania była przesuwna. Obciążenie przekazywano przez stalowy trawers na całej szerokości półki w sposób ciągły, przy użyciu siłownika o zakresie $200 \mathrm{kN}$, sterowanego przemieszczeniem z prędkością $10 \mu \mathrm{m} / \mathrm{s}$. Odkształcenia betonu mierzono w strefie ściskanej i rozciąganej za pomocą ułożonych poziomo czujników indukcyjnych, a na odcinku ścinania za pomocą równobocznych trójkątnych rozet, umieszczonych na bocznej powierzchni środnika. Analizę odkształcalności belek szczegółowo omówiono 
w publikacji [2], dlatego w niniejszym artykule te pomiary nie będą prezentowane. Pionowe przemieszczenia belek rejestrowano przy użyciu ośmiu czujników indukcyjnych zamocowanych do niezależnej stalowej ramy. Zachowanie belek pod obciążeniem monitorowano za pomocą systemu cyfrowej korelacji obrazu („digital image correlation” - DIC - ARAMIS), który rejestrował deformacje powierzchni belek (na przeciwległej stronie środnika) na polu o szerokości 500mm i wysokości środnika $340 \mathrm{~mm}$, położonym w środkowej części strefy ścinania. Proces obciążania elementów rejestrowano z prędkością 1 klatka na sekundę.

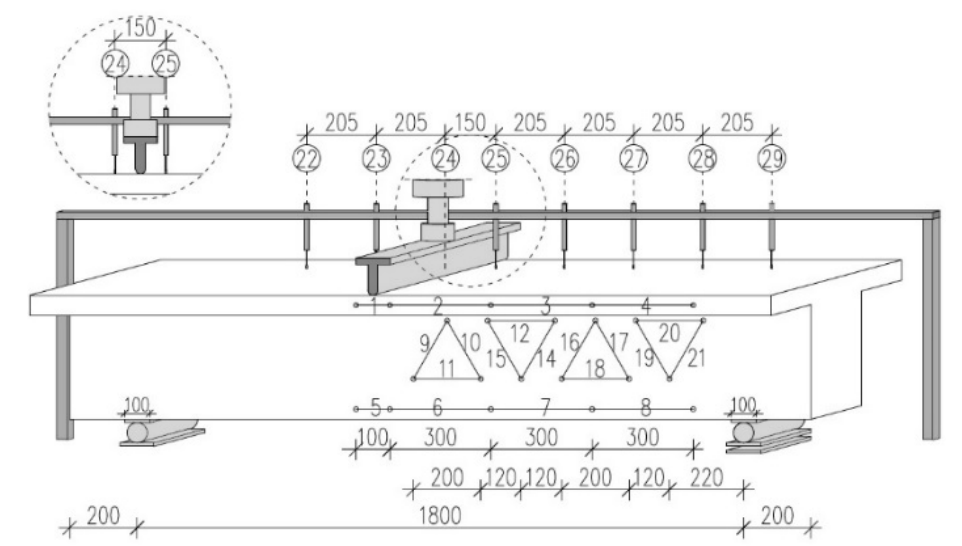

Rys. 2. Schemat statyczny i położenie czujników do pomiaru odkształceń betonu i przemieszczeń

Fig. 2. Test set-up and location of LVDT gauges for measuring of concrete strain and displacements

W celu wyeliminowania wpływu różnic użytecznych wysokości belek $d$ na siły niszczące $V_{u}$, dalszą analizę wyników badań przeprowadzono w odniesieniu do naprężeń ścinających $\tau_{u}=V_{u} /\left(b_{w} d\right)$. Zestawienie parametrów zmiennych, wyników badań betonu i belek przedstawiono w tabeli 1 .

Tabela 1. Szczegóły badanych belek

Table 1. Details of tested beams

\begin{tabular}{|c|c|c|c|c|c|c|c|c|}
\hline Element & $\begin{array}{c}\rho \\
{[\%]}\end{array}$ & $\begin{array}{c}f_{c, m} \\
{[\mathrm{MPa}]}\end{array}$ & $\begin{array}{c}f_{\text {ctm,sp }} \\
{[\mathrm{MPa}]}\end{array}$ & $\begin{array}{c}E_{c} \\
{[\mathrm{GPa}]}\end{array}$ & $\begin{array}{c}V_{u} \\
{[\mathrm{kN}]}\end{array}$ & $\begin{array}{c}\tau_{u} \\
{[\mathrm{MPa}]}\end{array}$ & $\begin{array}{c}\beta_{\text {test }} \\
{\left[{ }^{\circ}\right]}\end{array}$ & $\begin{array}{c}\beta_{\text {cal }}[1] \\
{\left[{ }^{\circ}\right]}\end{array}$ \\
\hline G-512-30-15 & 0,99 & 30,2 & 2,8 & 25,7 & 34,3 & 0,60 & 35 & 70 \\
\hline G-316-30-15 & 1,07 & 28,8 & 2,9 & 27,3 & 31,7 & 0,56 & 25 & 66 \\
\hline G-318-30-15 & 1,35 & 28,8 & 2,9 & 27,3 & 38,6 & 0,68 & 45 & 60 \\
\hline G-416-30-15 & 1,42 & 30,5 & 2,7 & 26,1 & 34,8 & 0,61 & 41 & 65 \\
\hline G-418-30-15 & 1,80 & 28,8 & 2,9 & 27,3 & 38,2 & 0,68 & 51 & 71 \\
\hline G-312/212-30-15 & 1,02 & 31,7 & 3,1 & 26,3 & 34,8 & 0,63 & 27 & 64 \\
\hline G-318/118-30-15 & 1,85 & 31,7 & 3,1 & 26,3 & 47,7 & 0,87 & 47 & 64 \\
\hline
\end{tabular}




\section{Wyniki badań}

Wszystkie elementy zniszczyły się na ścinanie. W pierwszej kolejności pojawiały się rysy typowe dla zginania, w środkowej części belki pod siłą obciążającą. Wraz ze wzrostem obciążenia rysy te rozwijały się w kierunku odcinka ścinania bez zbrojenia poprzecznego, aż do momentu, połączenia dwóch sąsiednich rys od zginania w jedną rysę ukośną, która na krótko po powstaniu zwiększała swoją rozwartość doprowadzając do zniszczenia na ścinanie. Zbrojenie podłużne było dobrze zakotwione i nie przejawiało objawów utraty zakotwienia nawet w chwili zniszczenia. Można w ten sposób określić sposób zniszczenia belek bez zbrojenia poprzecznego jako zginająco-ścinający, w którym rysy od zginania inicjują niszczenie na ścinanie. Jedyne jak dotąd kinetyczne podejście do analizy ścinania w żelbetowych belkach bez zbrojenia poprzecznego zaproponował Muttoni [6] lub mechaniczne Mari [5]. W myśl tych teorii niszczenie elementów może przebiegać stopniowo od zginania do ścinania (przez stopniową stabilizację układu rys od zginania) lub w nagły sposób (bez stopniowego rozwoju rys). Różnice w sposobach niszczenia na ścianie belek o $a / d>3,0$ są wynikiem różnego udziału przenoszenia naprężeń ścinających przez: ściskaną strefę betonu $V_{c}$, zazębiające się kruszywo $V_{a}$, siłę klockującą zbrojenie główne $V_{d}$ oraz nieznaczne rozcinające naprężenia w betonie $V_{t}$, co autorki szerzej opisały w [4].

Kinetyczny model niszczenia belek żelbetowych bez zbrojenia poprzecznego wg [1] wyodrębnia osiem typów rys „A” $\div$ „G”. Klasyczne, niemal pionowe rysy typu „A" powstałe $\mathrm{w}$ początkowej fazie obciążania elementu na skutek działania momentu zginającego, $\mathrm{w}$ miarę przesuwania się $\mathrm{w}$ kierunku podpory odchylają się w stronę punktowego obciążenia. Rysy te rozwijają się w kierunku ściskanej strefy przekroju osiągając zgodnie z założeniem modelu [1] przynajmniej połowę użytecznej wysokości przekroju $d_{f c t}>d / 2$, a kąt ich nachylenia $\beta$ określa prosta łącząca punkty przecięcia rysy z głównym zbrojeniem (punkt $\mathrm{P}_{1}$ ) i połową użytecznej wysokości przekroju (rys. 3c). Wartość tego kąta można policzyć ze wzoru (1) [1]:

$$
\beta=\arctan \left(1+1,25 \frac{M_{P_{1}}}{V_{P_{1}}}\right)
$$

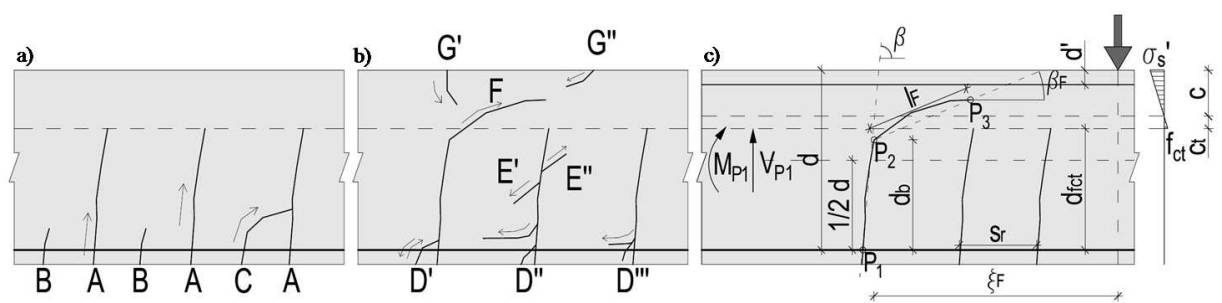

Rys. 3. Rodzaje rys w elementach żelbetowych bez zbrojenia poprzecznego wg [1]

Fig. 3. Type of cracks in steel reinforced elements without stirrups according to [1] 
Rysa typu „B” nosi miano wtórnej rysy od zginania, gdyż na ogół powstaje między dwiema sąsiadującymi rysami „A”. Rozwija się przy wyższym poziomie obciążenia, a jej zasięg jest mniejszy niż rysy pierwotnej. Rozstaw rys pierwotnych i wtórnych zależy przede wszystkim od warunków przyczepności zbrojenia podłużnego do betonu i jego stopnia zbrojenia oraz jak dalej wykażą autorki również od liczby prętów, ich średnicy oraz liczby poziomów tego zbrojenia.

Rysa typu „C” powstaje z połączenia pierwotnej rysy „A" z wtórną rysą „B”. Rozwarstwiająca rysa typu „D” świadczy o oddziaływaniu klocującego efektu zbrojenia podłużnego i może wystąpić w trzech formach, jako „, $\mathrm{D}^{\prime}$ ”, , „D" "oraz „, $\mathrm{D}^{\prime \prime \prime}$ ” (rys. 3b). Rysa typu „E” jest przykładem efektu zazębiania się kruszywa, może więc ona powstać po obu stronach istniejących rys typu „A” (,E' ”, lub „E" ”). Rysa typu „F” jest kontynuacją pierwotnej rysy „A”, która po zmianie kierunku na prawie poziomy rozwija się w kierunku ściskanej krawędzi belki. Rysa typu „G” pojawia się w obrębie ściskanej strefy przekroju i jako jedyna nie ma związku z pozostałymi rysami, może przyjmować postać odchylonych rys typu (, $\mathrm{G}^{\prime}$ ” lub „, $\mathrm{G}^{\prime \prime}$ ”).

Analiza własnych badań belek zbrojonych prętami GFRP wykonana przy użyciu systemu do pomiarów optycznych ARAMIS pozwoliła szczegółowo opisać mechanizm niszczenia każdej z belek oraz na podstawie obrazu rysy niszczącej, określić wpływ parametrów zmiennych zbrojenia podłużnego na kąt nachylenia tej rysy $\beta$. Na rys. 4. przedstawiono rozwój zarysowania belek zarejestrowany metodą DIC dla trzech wybranych poziomów obciążenia belki odpowiadających dwóm wybranym siłom poprzecznym $V_{l}$ i $V_{2}$ oraz sile niszczącej $V_{u}$. Z uwagi na ograniczone pole rejestracji odkształceń tą metodą (oznaczone na rysunkach niebieską, przerywaną linią), analiza obrazu rysy ukośnej możliwa była tylko w zakresie tego pola. Niemniej jednak na podstawie zdjęć całego odcinka ścinania po zniszczeniu elementu, możliwa była precyzyjna analiza rozwoju zarysowania tej strefy, również poza odcinkiem bezpośrednio rejestrowanym metodą DIC. To pozwoliło szczegółowo opisać stopniowy rozwój zarysowania elementu w całym zakresie obciążeń. Obliczone na podstawie wzoru (1) wg [1] kąty nachylenia rysy niszczącej $\beta_{c a l}$ zamieszczono w tab. 1 oraz na rysunkach układu rys wybranych belek po zniszczeniu (rys. 4.).

Pierwotne rysy od zginania typu „A” wystąpiły we wszystkich analizowanych elementach, a ich maksymalny zasięg obejmował wysokość całego środnika $(300 \mathrm{~mm})$, co jest $\mathrm{w}$ pełni zgodne z założeniem $d_{f c t}>d / 2$ [1]. Więcej wtórnych rys typu „B” pojawiło się w elementach ze stopniem zbrojenia $\geq 1,4 \%$. Rysa typu „F” pojawiła się w prawie wszystkich belkach (poza G-512-30-15). Ukośna rysa niszcząca pojawiała się w odległości $0,9 d \div 1,8 d$ od osi podpory, a jej długość wahała się w przedziale $0,26 d \div 0,80 d$. Niezależnie od liczby poziomów zbrojenia wraz z przesuwaniem się rysy ukośnej w stronę podpory odnotowano wzrost jej długości. 


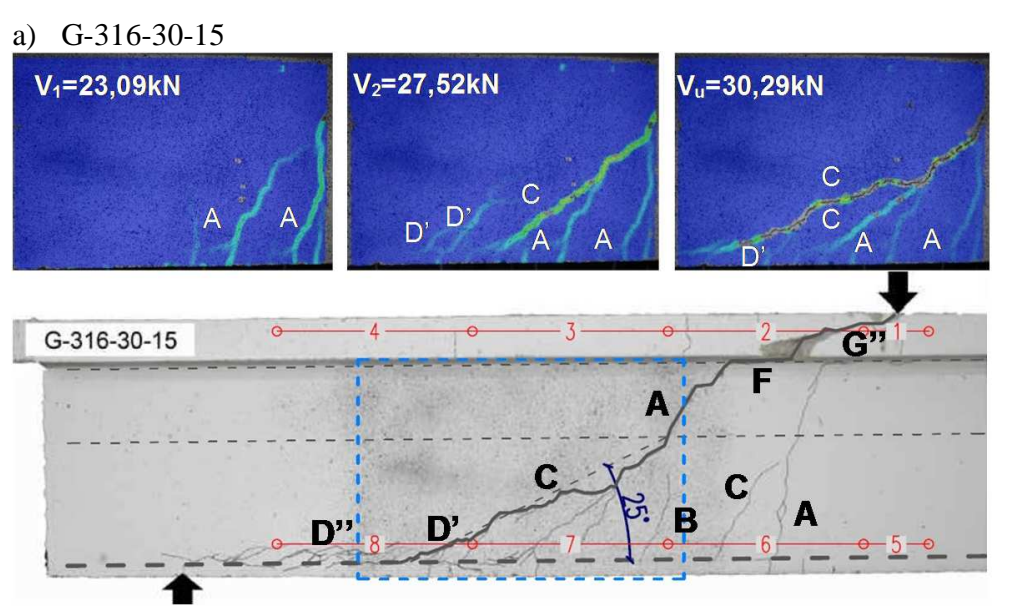

b) G-318-30-15
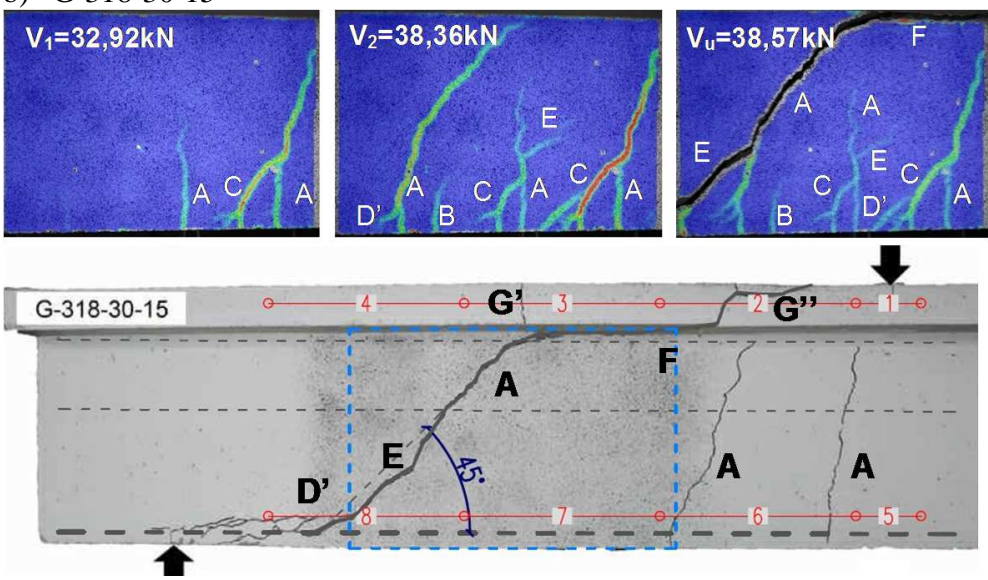

c) G-318/118-30-15
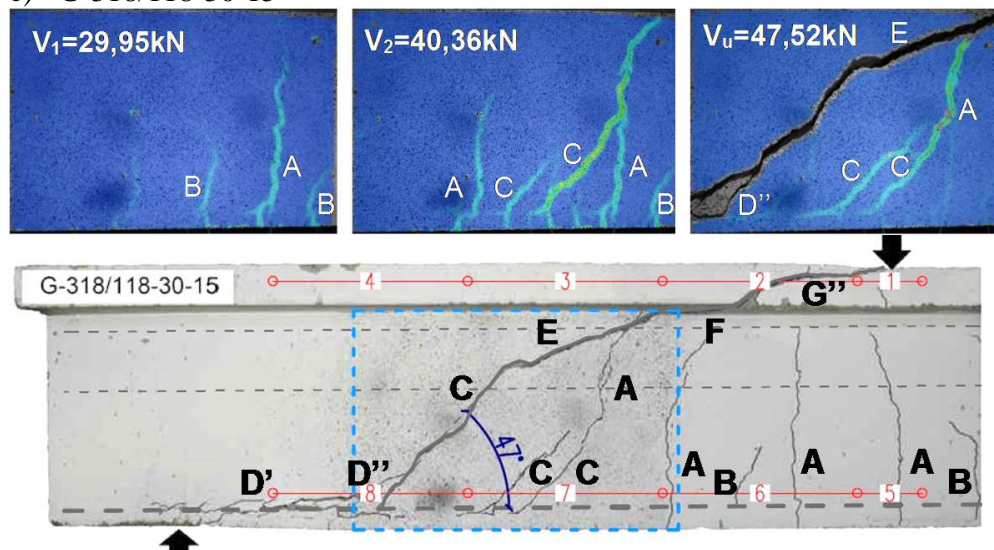

Rys. 4. Sposób zarysowania wybranych belek

Fig. 4. Crack pattern of selected beams 
Na uwagę zasługuje znacznie wyższe położenie tej rysy typu „F” w badanych belkach teowych (tuż pod półką) w porównaniu z belkami prostokątnymi [1]. Zdaniem autorek jest to wynikiem wpływu teowego przekroju belek na większy udział ściskanej strefy betonu $V_{c}$, co jednocześnie potwierdza opinię o wpływie kształtu przekroju teowego na wyższą nośność ścinania w porównaniu z identycznie zbrojonymi belkami o przekroju prostokątnym.

\section{Analiza wpływu zbrojenia podłużnego}

Jednym z podstawowych parametrów zmiennych analizowanych $\mathrm{w}$ badaniach był wpływ zbrojenia głównego. $\mathrm{Z}$ porównania naprężeń niszczących $\tau_{u}$ belek wynika, że wraz ze wzrostem tego stopnia rosła wartość granicznych naprężeń ścinających (tab. 1, rys. 5.), przy czym naprężenia te wahały się w granicach $0,56 \div 0,63$ MPa dla $\rho \approx 1,0 \%$ (niezależnie od liczby poziomów zbrojenia); $0,61 \div 0,68 \mathrm{MPa}$ dla $\rho \approx 1,4 \%$. Dużą różnicę wartości naprężeń niszczących $0,68 \mathrm{MPa}$ i $0,87 \mathrm{MPa}$ odnotowano dla belek o $\rho \approx 1,8 \%$, odpowiednio ze zbrojeniem ułożonym w jednej i dwóch warstwach, czego powodem mogła być zarówno wyższa wytrzymałość betonu, jak i wyższy stopień zbrojenia podłużnego $\rho=1,85 \%$ belki G-318/118-30-15. Średnie naprężenia niszczące wyniosły $\tau_{u}=0,2 f_{c t m, s p}$, a jedynie $\mathrm{w}$ belce o najwyższym stopniu zbrojenia, ułożonego w dwóch warstwach, naprężenia te osiągnęły wartość $\tau_{u}=0,28 f_{c t m, s p}$.

Stopień zbrojenia głównego miał również wpływ na kąt nachylenia ukośnej rysy niszczącej, określonej wcześniej jako $\beta$ wg [1]. Wraz ze wzrostem stopnia zbrojenia głównego rysy ukośne nachylone były pod wyższym kątem do podłużnej osi belki (dla $\rho \approx 1,0 \%, \beta=25-35^{\circ}$; dla $\rho \approx 1,4 \%, \beta=41-45^{\circ}$; dla $\rho \approx 1,8 \%, \beta=47-51^{\circ}$, Tab. 1., rys. 6.). Nie zaobserwowano większych różnic w naprężeniach niszczących i kącie nachylenia rysy niszczącej między belkami o podobnych stopniach zbrojenia głównego, ale różniących się liczbą prętów i ich średnicą.

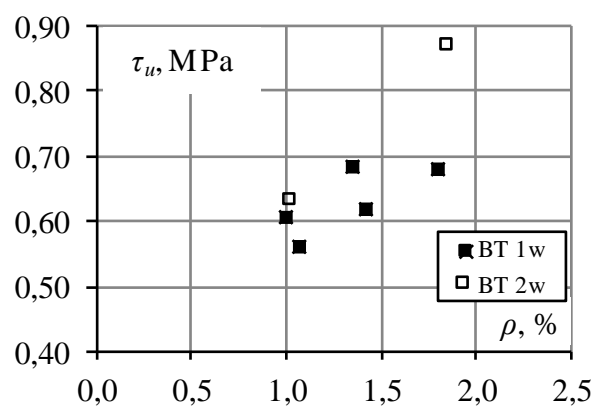

Rys. 5. Zależność naprężeń niszczących od stopnia zbrojenia podłużnego

Fig. 5. Response of ultimate shear stress - reinforcement ratio

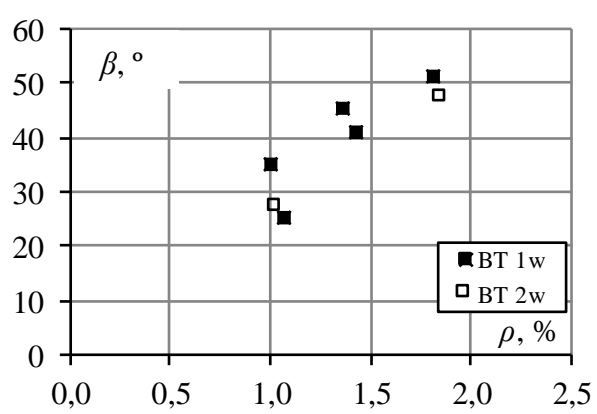

Rys. 6. Zależność kąta nachylenia rysy niszczącej od stopnia zbrojenia podłużnego

Fig. 6. Response of angle of shear crack reinforcement ratio 
Na rysunku 7. przedstawiono zależność naprężenie ścinające - ugięcie (obliczone jako średnia wartość ze wskazań dwóch czujników położonych w bezpośrednim sąsiedztwie siły obciążającej - czujniki nr 24 i 25, rys. 2.). Z porównania wykresów ugięć wynika, że w ramach grupy belek o jednakowym stopniu zbrojenia, ich sztywność była porównywalna, natomiast wyraźne różnice naprężeń niszczących i ugięć można zaobserwować między grupami belek o różnym stopniu zbrojenia głównego.

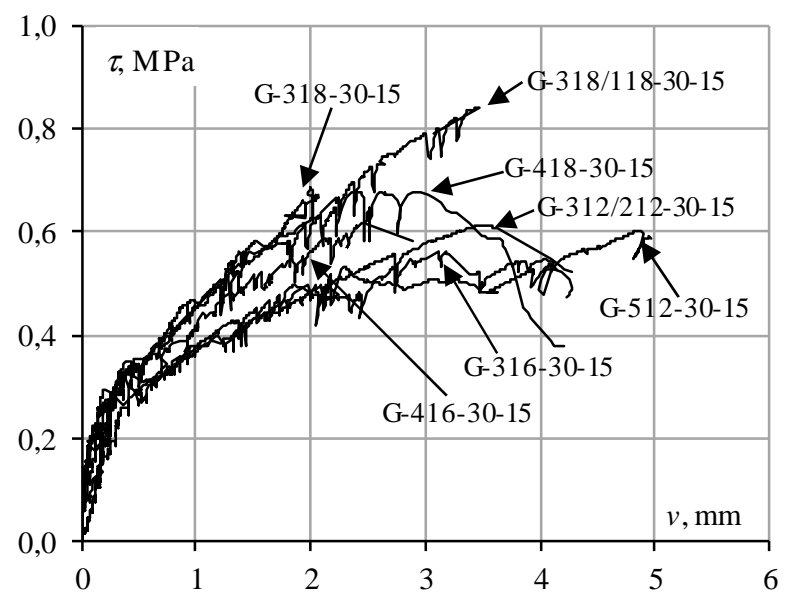

Rys. 7. Zależność naprężenie ścinające-średnie ugięcie w punkcie obciążenia belek

Fig. 7. Response of the shear stress-average displacement in the load point of tested beams

Belki najsłabiej zbrojone osiągnęły najwyższe ugięcia ok. 5mm, podczas gdy wraz ze wzrostem stopnia zbrojenia głównego odkształcalność belek malała, co widać po niższych wartościach maksymalnych przemieszczeń pionowych. Ponadto widać, że belki o stopniu zbrojenia głównego $\rho \geq 1,35 \%$ w ramach tej samej grupy są bardziej wrażliwe na zmianę liczby prętów i średnicę niż belki słabiej zbrojone (rys. 7.). Z porównania naprężeń ścinających w belkach o tym samym stopniu zbrojenia, ułożonym w jednej lub dwóch warstwach wynika, że dwie warstwy zbrojenia wzmocniły efekt ,tension stiffening”, przez co belki te osiągnęły wyższe naprężenia niszczące, a dodatkowo „zszycie” rysy zbrojeniem ułożonym w dwóch warstwach zwiększyło ich odkształcalność.

Ponieważ zależność kąta nachylenia ukośnej rysy niszczącej została określona w modelu [1] w funkcji momentu zginającego $M_{P I}$ i siły poprzecznej $V_{P I}$ w punkcie $\mathrm{P}_{1}$ dla belek żelbetowych obciążonych obciążeniem rozproszonym, autorki sprawdziły, jak zależność opisana wzorem (1) sprawdza się dla belek z głównym zbrojeniem GFRP, które jak wiadomo charakteryzuje czterokrotnie mniejszy moduł sprężystości w porównaniu ze zbrojeniem stalowym, jak i dużo niższa przyczepność tego zbrojenia do betonu. Ponadto dodatkową różnicę stanowił schemat obciążenia belek opisanych $\mathrm{w}$ [1] w porównaniu $\mathrm{z}$ belkami auto- 
rek. Obliczeniowe wartości kątów $\beta_{\text {cal. }}$ porównano z rzeczywistymi wartościami kątów $\beta_{\text {test }}$ określonymi na rys. 4 i w tabeli 1 . Jak widać wartości obliczeniowe kątów $\beta_{\text {cal }}$ znacząco przewyższają te $\mathrm{z}$ badań $\beta_{\text {test. }}$ Zdaniem autorek powodem tych różnic jest przede wszystkim typ zbrojenia. Aby potwierdzić te przypuszczenia autorki wykonały drugą serię belek z podłużnym zbrojeniem stalowym, która pozwoli precyzyjnie ten wpływ określić.

\section{Podsumowanie}

W pracy przedstawiono wyniki własnych badań doświadczalnych wraz ze szczegółową analizą mechanizmów niszczenia na ścianie belek zbrojonych na zginanie prętami GFRP, bez zbrojenia poprzecznego. Korzystając z rejestracji zarysowania, prowadzonego za pomocą systemu cyfrowej korelacji obrazu ARAMIS, wyjaśniono proces niszczenia zginająco-ścinającego z analizą kolejnych faz rozwoju zarysowania i sposobem określania położenia ukośnej rysy niszczącej. $\mathrm{Z}$ analizy wpływu zbrojenia głównego wynika, że niszczące naprężenia ścinające rosną wraz ze wzrostem stopnia tego zbrojenia, przy czym wpływ liczby prętów i ich średnicy na ogół nie jest istotny, natomiast większe znacznie odgrywa liczba jego warstw, zwłaszcza przy najwyższym stopniu zbrojenia $\rho=1,85 \%$. Ponadto wraz ze wzrostem stopnia zbrojenia widoczny jest wprost proporcjonalny przyrost nachylenia ukośnej rysy niszczącej $\beta_{\text {test }}$ - od wartości $25^{\circ}$ dla $\rho \approx 1,0 \%$ do $51^{\circ}$ dla $\rho \approx 1,8 \%$.

Analiza obliczeniowej zależności kąta $\beta_{c a l}$ w funkcji $M_{P 1} /\left(V_{P 1} d\right)$ wg [1] wykazała znacznie wyższe obliczeniowe, w porównaniu z doświadczalnymi, wartości kątów nachylenia tej rysy. Badania zaprezentowane w pracy stanowią część szerszego programu autorek, dlatego uogólnienie powyższych wniosków wymaga dalszej analizy obejmującej dodatkowo belki zbrojone tradycyjnym zbrojeniem stalowym oraz belki różniące się wytrzymałością betonu.

Autorki pragną podziękować firmie Comrebars za udostępnienie niemetalicznego zbrojenia GFRP do całego programu badawczego.

\section{Literatura}

[1] Cavagnis F., Fernández Ruiz M., Muttoni A. (2015). "Shear failures in reinforced concrete members without transverse reinforcement: An analysis of the critical shear crack development on the basis of test results". Engineering Structures 103, 157-173.

[2] Kaszubska M., Kotynia R., Barros J.A.O.: Influence of longitudinal GFRP reinforcement ratio on shear capacity of concrete beams without stirrups. AMCM 2017 (przyjęty do druku).

[3] Knauff M., "Obliczanie konstrukcji żelbetowych według Eurokodu 2". Wydawnictwo Naukowe PWN SA, 2013.

[4] Kotynia R., Kaszubska M.: Nośność na ścinanie belek betonowych zbrojonych prętami kompozytowymi bez zbrojenia poprzecznego w świetle badań obcych. Inżynieria i Budownictwo, 12/2016. 
[5] Marí A., Cladera A., Oller E., Bairán J.: Shear design of FRP reinforced concrete beams without transverse reinforcement. "Composites: Part B", 57, 2014.

[6] Muttoni A, Fernández Ruiz M. Shear strength of members without transverse reinforcement as function of critical shear crack width. ACI Structural Journal 2008;105(2):163-72. Farmington Hills, USA.

[7] Reineck, K.-H., Review of basic assumptions for the shear design. Paper SP 265-17 in: Thomas T.C. Hsu Symposium, Part 3, Five decades of progress in shear. ACI SP $265,2009$.

\section{INFLUENCE OF NONMETALLIC FLEXURAL REINFORCEMENT ON FAILURE MECHANISMS AND SHEAR CAPACITY OF CONCRETE BEAMS WITHOUT TRANSVERSAL REINFORCEMENT}

\section{S u m m a r y}

The paper presents experimental test results of concrete beams with longitudinal GFRP reinforcement without transversal reinforcement. The aim of the test was analysis of the beams' behavior under loading and influence of the flexural reinforcement on the failure mechanism and the shear capacity. For analysis of the beams' deformability the digital image correlation system ARAMIS was used. Based on kinematic shear model the process of failure was described in details with location of the critical shear crack and its inclination. Test results indicated that the ultimate shear stress increases with increase in the flexural reinforcement ratio, while the shear stress is not affected by a number of the bars and their diameter. Much more affected was a number of the reinforcement levels, especially in the beam with the highest longitudinal reinforcement ratio.

Keywords: concrete beam, non-metallic reinforcement, GFRP rebar, shear capacity, failure mechanism, cracking, shear stress, reinforcement ratio

Przestano do redakcji: 01.06.2017 r.

Przyjęto do druku: 01.09.2017 r. 